\title{
Effect of selective gastric vagotomy on histamine concentration in gastric mucosa of patients with duodenal ulcer
}

\author{
H. TROIDL, H. ROHDE, W. LORENZ, G. HÄFNER AND H. HAMELMANN*
}

\section{SUMMARY}

In a prospective controlled trial, histamine concentrations in human gastric mucosa were determined fluorometrically in 23 patients $6-11$ months after selective gastric vagotomy with drainage and in patients who had undergone other types of operation for duodenal ulcer. The study was in two parts: part 1 , a synchronous investigation of mucosal histamine concentrations in patients who had undergone vagotomy, in duodenal ulcer patients before operation and in control subjects; part 2, a consecutive study of the same patients before and after vagotomy.

In part 1, patients with Hollander-negative vagotomy were found to have significantly higher mucosal histamine concentrations than 'healthy' control subjects or duodenal ulcer patients before operation. Patients with recurrent ulcer, however, had as low mucosal histamine concentrations as duodenal uicer patients who had not been operated on. In part 2, all duodenal ulcer patients showed an increase in gastric mucosal histamine concentration after vagotomy $(P<0.01)$. The smallest increase was in a patient with an incomplete vagotomy. Control patients who were not operated on but who underwent endoscopy and biopsy twice in the period of investigation, did not show any increase in mucosal histamine concentration between the times of the first and the second biopsy. The overall results of selective vagotomy and drainage in this study, with respect both to clinical Visick gradings and to radiological and acid secretory findings, were comparable to those reported by other authors. No significant change in numbers of parietal cells was found after vagotomy. Thus, selective gastric vagotomy with a drainage procedure leads to increased concentrations of histamine in the mucosa of the body of the stomach in man. The mechanism is not clear, but might be through inhibition of histamine release from mast cell stores.

A REMARKABLE feature of several review articles on the pathological functions of histamine published in the past 15 years has been that a relationship of this substance to peptic ulceration has either not been mentioned at all, or else has been considered to be of only minor significance (Dunér and Pernow, 1960; Code et al., 1964; Lindell and Westling, 1966). There were several reasons for this; for example, although gastric ulcers were produced in rats by subcutaneous injections of histamine (Büchner et al., 1928) and duodenal ulcers were produced in dogs by intramuscular histamine in beeswax (Varco et al., 1941), it became increasingly evident that the clinical counterparts in man of these observations in animals were more in the form of acute haemorrhagic lesions (stress ulcers) than of chronic duodenal ulcers (Lorenz and Feifel, 1970; Seidel et al., 1973a; Lorenz et al., 1974). Secondly, attempts to correlate changes in the histamine content of whole blood, gastric juice and tissue with the occurrence or prevalence of peptic ulcer yielded conflicting results. Thus, the finding of elevated blood histamine concentrations in patients with florid duodenal ulcer (Riboli, 1940; Parrot et al., 1943) was thought to be due to increased mobilization of stored histamine (Guggenheim, 1951). However, these observations either could not be confirmed (Shimkin et al., 1943) or else seemed to be true for only a minority of patients (Lips et al., 1947; Surkes, 1948). We know that the histamine content of whole blood is a poor index of histamine release in man (Lorenz et al., 1972). In a small number of patients, Smith (1959) found no difference in the histamine content of gastric body mucosa when he compared duodenal ulcer patients with patients who had gastric carcinoma. Similarly, Borbola et al. (1951) were unable to detect significant differences between the histamine concentrations in the gastric juice of control subjects and that of patients with duodenal ulcer. A special case-but none the less remarkablewas the finding of increased urinary excretion of histamine in patients with the Zollinger-Ellison syndrome (Dotevall et al., 1963; Dotevall and Walan, 1970). This finding did not apply to duodenal ulcer patients in general (Bjurö, 1963). Finally, studies on mucosal histamine formation did not show any significant difference between patients with duodenal uicer and those with gastric carcinoma (Lindell and Westling, 1966). Thus, until recently, the hypothesis that histamine was involved in human peptic ulcer disease lacked corroborative evidence.

Two observations which have been made quite recently, however, have put histamine back into the reckoning. First, histamine $\mathrm{H}_{2}$-receptor antagonists were shown to heal peptic ulcers in man (International Multicentre Trial, 1975); secondly, storage and inactivation of histamine in the acid-producing gastric mucosa of duodenal ulcer patients were shown to be different from storage and inactivation in control subjects (Troidl et al., 1976a; Barth et al., 1977).

Since vagotomy is known to reduce gastric acid secretion, we decided to investigate the effect of vagotomy on the histamine stores in the mucosa of the body of the stomach in man. Preliminary reports of this work have already been published (Troidl et al., 1975a, 1976b).

\section{Patients and methods}

Design and protocols of the study

Tissue histamine content, especially the histamine content of gastric mucosa, is influenced by numerous genetic, humoral and environmental factors (Lorenz and Pfleger, 1968; Lorenz

* Surgical Clinic and Division of Experimental Surgery and Pathological Biochemistry, University of Marburg/Lahn.

Correspondence to: Dr H. Troidl, Surgical Clinic of the University, Robert-Koch-Strasse 8, 3550Marburg/Lahn, West Germany. 


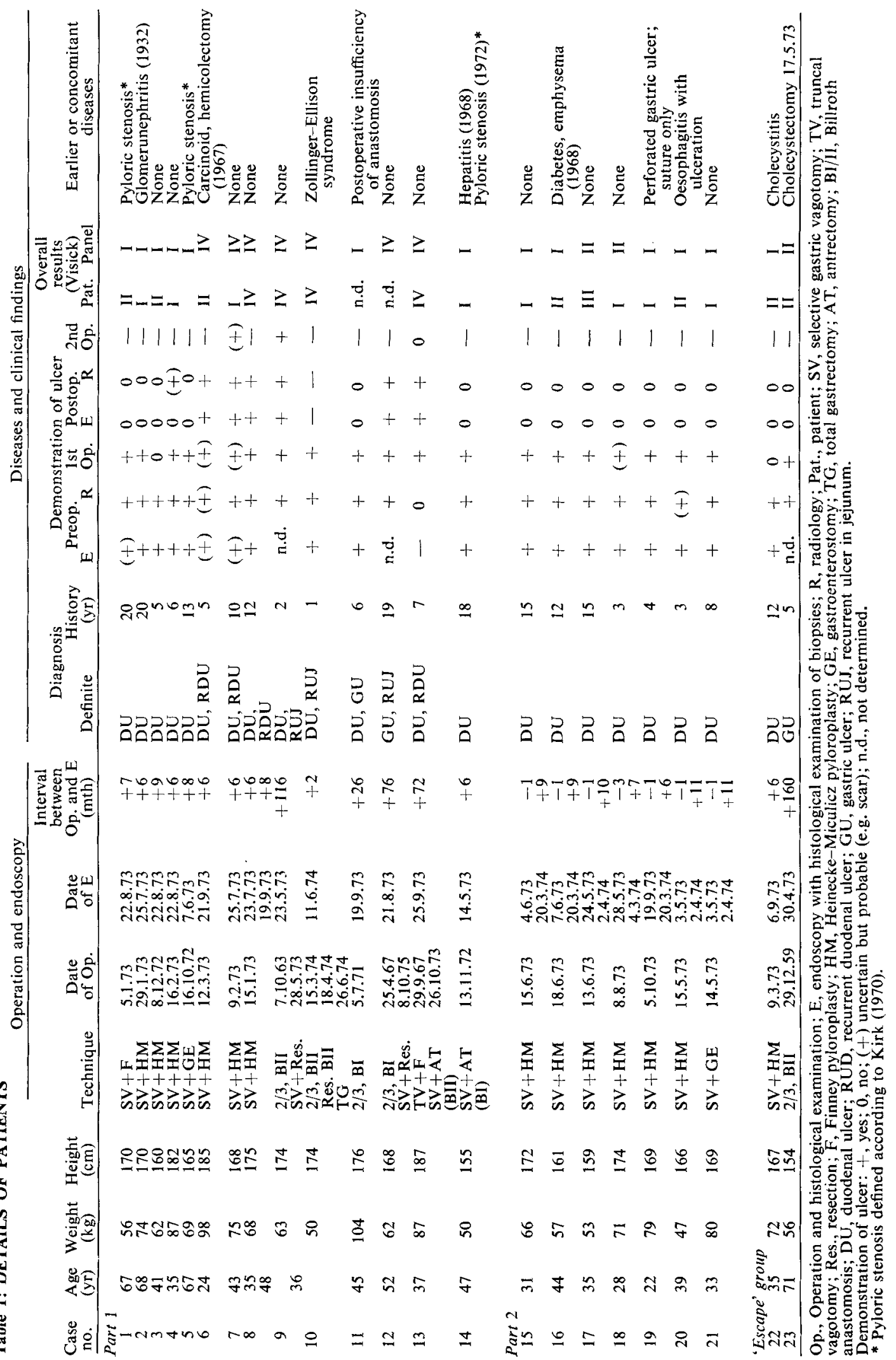


Table II: HISTAMINE CONCENTRATIONS IN CORPUS MUCOSA OF PATIENTS WITH DUODENAL AND GASTRIC ULCER AFTER OPERATION

\begin{tabular}{|c|c|c|c|c|c|c|}
\hline \multirow{3}{*}{$\begin{array}{c}\text { Case } \\
\text { no. }\end{array}$} & \multirow{2}{*}{\multicolumn{2}{|c|}{ Response to insulin }} & \multicolumn{4}{|c|}{ Histamine content $(\mu \mathrm{g} / \mathrm{g})$} \\
\hline & & & \multicolumn{2}{|c|}{ Sample } & \multirow[b]{2}{*}{3} & \multirow{2}{*}{$\begin{array}{c}\bar{x} \text { of } \\
\text { samples }\end{array}$} \\
\hline & Hollander & Bachrach & 1 & 2 & & \\
\hline \multicolumn{7}{|l|}{$S V$} \\
\hline 1 & - & - & $51 \cdot 3$ & $41 \cdot 0$ & $51 \cdot 5$ & $47 \cdot 9$ \\
\hline 2 & - & -- & 61.5 & 41.5 & $46 \cdot 0$ & $49 \cdot 7$ \\
\hline 3 & - & - & $38 \cdot 1$ & $60 \cdot 0$ & $56 \cdot 7$ & $51 \cdot 6$ \\
\hline 4 & - & -- & $56 \cdot 5$ & 68.0 & 66.0 & 63.5 \\
\hline 5 & - & - & $80 \cdot 0$ & $66 \cdot 8$ & $59 \cdot 6$ & $68 \cdot 8$ \\
\hline
\end{tabular}

$S V$ and recurrent ulcer

$\begin{array}{lllllll}6 & - & - & 38.0 & 36.0 & 24 \cdot 6 & 32.9 \\ 7 & + & + & 29.4 & 37.6 & 38 \cdot 0 & 35.0 \\ 8 & - & - & 35.2 & 38.4 & 37 \cdot 4 & 37.0\end{array}$

Other operative procedures

\begin{tabular}{rrrrrrr}
9 & + & + & 6.9 & $11 \cdot 3$ & 11.2 & 9.8 \\
10 & + & + & 15.4 & 10.4 & 14.1 & 13.3 \\
11 & + & + & 41.5 & $40 \cdot 1$ & $41 \cdot 7$ & 41.1 \\
12 & n.d. & n.d. & 71.5 & 59.5 & 59.5 & 63.5 \\
13 & + & + & 51.6 & 44.1 & 58.5 & 51.4 \\
14 & - & - & 84.5 & 58.0 & 69.5 & 70.7 \\
& & & & & & \\
'Escape' & group & & & & & \\
22 & + & - & 95.5 & 90.5 & 12.0 & 102.0 \\
23 & + & + & 76.5 & 57.0 & 37.5 & 57.0 \\
\hline
\end{tabular}

SV, Selective gastric vagotomy. Response to insulin: + , positive; - , negative; n.d., not determined.

The median value for Cases $1-5$ is $51.6 \mu \mathrm{g} / \mathrm{g}$, for Cases $6-8$ $350 \mu \mathrm{g} / \mathrm{g}$.

et al., 1973). Since in a study on histamine and vagotomy all these factors may act as covariables which are difficult to define and very difficult to control, we used two experimental concepts in the same trial.

Part 1: a synchronous investigation of vagotomized subjects, duodenal ulcer patients before operation and various other groups of subjects acting as controls: In a prospective study, lasting from April to September 1973, biopsies of gastric mucosa were taken for histamine estimation in 100 consecutive patients who were admitted for endoscopy in our gastroenterology unit by physicians not involved in the study (for details see Troidl et al., 1976a). Biopsies were also obtained from 3 patients with recurrent ulcer (Cases 6, 8 and 13, Table I) who were admitted for endoscopy in September 1973 soon after the prospective study ended. Two of the 103 patients who were operated on were excluded from the trial because of cholecystitis, which has an influence on gastric histamine content (Troidl et al., 1976a) (Table I).

Part 2: consecutive investigation of the same subjects before and after vagotomy: All duodenal ulcer patients who were included in the prospective study (see above) and who subsequently underwent vagotomy were included in the second part of our trial (Table $I$ ). Thus, in this part of the study control subjects and vagotomized patients were not tested synchronously; but since the patients served as their own controls it was possible to exclude many variables which had not been excluded in the first part of the trial.

The use of these two experimental concepts ensured that none of the subjects was selected for the trial by fortuitous, undefined and uncontrolled criteria (Table I).

Biopsies were obtained from a total of 106 patients from Marburg and the surrounding area; these included the 103 individuals from parts 1 and 2 of the study and 3 additional patients who were included only to show the reproducibility of the histamine assay (Table $I I I$ ). All duodenal ulcer patients submitted to selective gastric vagotomy and drainage were studied or reinvestigated 6-11 months after operation (Table I). After this interval, the effects of the operative procedure on such factors as acid secretion (Lyndon et al., 1973) and gastric motility and emptying (Sheiner et al., 1975) were considered to be relatively stable.

The design of the study, which has been described in detail elsewhere (Troidl et al., 1976a), included case history, a clinical questionnaire, oesophagogastroduodenoscopy, pathological examination of the biopsy specimens, radiology of the stomach, intestine and biliary tract, gastric secretory tests (pentagastrin and insulin) and recording of operative findings in patients coming to surgery. The diagnoses were established according to Troidl et al. (1976a) and Rohde et al. (1977). Control subjects and patients were classified according to the present diagnosis, concomitant diseases and previous history (Troidl et al., 1976a). By these criteria, 2 of the patients who had been operated on for peptic ulcer were excluded from the trial (Table I). To avoid the introduction of bias, the results of the histamine estimations were not recorded until the patients had been finally classified.

\section{Patients}

The 106 male and female patients in the trial included 32 control subjects, 11 patients with duodenal ulcer without subsequent operation, 40 patients with various other abdominal diseases (Troidl et al., 1976a) and 23 patients who underwent operation for duodenal or gastric ulcer (Table I). Since all patients treated surgically in the trial were male, only the 21 male control subjects and 17 male duodenal ulcer patients $(10$ without operation, 7 before operation, Table I) were considered in the comparison of gastric mucosal histamine concentration. The control subjects were patients with non-specific abdominal complaints who had been found to be 'healthy' with respect to their upper gastrointestinal tract. The duodenal ulcer patients were those in whom the presence of the ulcer was established by endoscopy, radiology and histological examination.

The characteristics of the patients with duodenal and gastric ulcer who were treated by various operations are shown in Table I. These data on the patients, the operations performed, endoscopic findings and concomitant diseases are given because we know nothing at present about the possible influences of various covariables (Byar et al., 1976) on gastric histamine content in man, but must suspect from the results of experiments in animals that there are many such influences (Lorenz and Pfleger, 1968; Troidl et al., 1976a). Thus, it seemed important to be able to compare the patients whom we studied after operation with patients studied by other authors (Troidl et al., 1975b). Furthermore, the mean reductions in basal and pentagastrin-stimulated acid output in our patients after selective gastric vagotomy with drainage were 82 and 52 per cent respectively, and the incidence of positive Hollander tests was 18 per cent, indicating the outcome to be expected after this type of operation (Troidl et al., 1975b). Finally, the definition of recurrent ulceration was that used by Weinberg (1964).

\section{Methods}

Fluorometric assay of histamine in biopsy specimens: Four samples were taken during endoscopy, 3 for histamine assay and 1 for histological examination. Histamine concentration was determined by a slight modification of our Dowex method (Lorenz et al., 1970) as described by Troidl et al. (1976a). It was expressed as microgrammes of histamine dihydrochloride per gramme wet weight of mucosa. The specificity of the assay was confirmed by fluorescence spectra, formaldehyde and heating test, inactivation of the isolated substance by purified histamine methyltransferase from pig antrum, by purified diamine oxidase from pig kidney and by bioassay on the isolated guinea-pig ileum (Lorenz et al., 1978). The precision of the entire procedure (sample taking, homogenization and determination of histamine) within the day was $11 \cdot 6 \pm 4 \cdot 0$ (coefficient of variation, VC per cent) in 3 series of 9 experiments when the mean value from 3 biopsies was used for a single estimation. The accuracy of the test was found to be satisfactory by comparing the values obtained by fluorometry with those obtained by bioassay as a 'reference' method (Rohde et al., 1978). A time interval of up to $7 \mathrm{~min}$ between the taking of the biopsy and its fixation in $2 \mathrm{ml} 1 \mathrm{M} \mathrm{HClO}_{4}$ 
Table III: REPRODUCIBILITY OF HISTAMINE ASSAY

\begin{tabular}{|c|c|c|c|c|c|c|}
\hline \multirow[b]{2}{*}{ Diagnosis and operation } & \multirow[b]{2}{*}{$\begin{array}{l}\text { Date } \\
\text { of } E\end{array}$} & \multicolumn{4}{|c|}{ Histamine content $(\mu \mathrm{g} / \mathrm{g})$} & \multirow[b]{2}{*}{$\begin{array}{c}\text { Difference } \\
( \pm \%)\end{array}$} \\
\hline & & 1 & $\begin{array}{c}\text { Sample } \\
2\end{array}$ & 3 & $\begin{array}{c}\bar{x} \text { of } \\
\text { samples }\end{array}$ & \\
\hline \multicolumn{7}{|l|}{ Reproducibility within the same day } \\
\hline \multirow[t]{2}{*}{ Alimentary obesity and DU } & 6.8 .75 & $14 \cdot 6$ & $32 \cdot 0$ & $17 \cdot 5$ & $21 \cdot 4$ & \\
\hline & 6.8 .75 & $18 \cdot 2$ & $13 \cdot 1$ & $24 \cdot 3$ & $18 \cdot 5$ & -14 \\
\hline \multirow{2}{*}{ Diabetes, intra-abdominal trauma } & 13.9 .73 & $74 \cdot 4$ & $69 \cdot 6$ & $64 \cdot 8$ & $69 \cdot 6$ & \\
\hline & 13.9 .73 & $104 \cdot 4$ & $72 \cdot 0$ & $72 \cdot 0$ & $82 \cdot 8$ & +19 \\
\hline \multirow{2}{*}{ DU after $2 / 3$ BI Res. } & 6.8 .75 & $17 \cdot 4$ & $21 \cdot 1$ & $15 \cdot 9$ & $18 \cdot 1$ & \\
\hline & 6.8 .75 & $17 \cdot 0$ & $13 \cdot 3$ & $16 \cdot 0$ & $15 \cdot 4$ & -15 \\
\hline \multicolumn{7}{|l|}{ Reproducibility from day to day } \\
\hline \multirow[t]{2}{*}{ GU, cholecystectomy } & 30.4 .73 & $55 \cdot 5$ & $108 \cdot 0$ & $72 \cdot 5$ & $78 \cdot 7$ & \\
\hline & 14.8 .73 & $59 \cdot 5$ & $71 \cdot 5$ & $76 \cdot 5$ & $69 \cdot 2$ & -12 \\
\hline DU without RDU & 23.7 .73 & $39 \cdot 2$ & $40 \cdot 2$ & $44 \cdot 5$ & $41 \cdot 3$ & \\
\hline DU with RDU & 19.9 .73 & $35 \cdot 2$ & $38 \cdot 4$ & $37 \cdot 4$ & $37 \cdot 0$ & -8 \\
\hline \multirow[t]{2}{*}{ Alimentary obesity } & 16.4 .73 & $28 \cdot 8$ & $53 \cdot 1$ & $53 \cdot 4$ & $45-1$ & \\
\hline & 30.4 .73 & $47 \cdot 3$ & $34 \cdot 6$ & $40 \cdot 8$ & $40 \cdot 9$ & -9 \\
\hline \multirow{2}{*}{ Control subject } & 21.9 .73 & $39 \cdot 1$ & $50 \cdot 4$ & $28 \cdot 7$ & $39 \cdot 4$ & \\
\hline & 25.9 .73 & $46 \cdot 4$ & $40 \cdot 3$ & $49 \cdot 9$ & $43 \cdot 9$ & +11 \\
\hline
\end{tabular}

For abbreviations, see Table 1 .

For within-day tests, 2 patients from 1975 were included, for day-to-day tests only patients who came within the period of the trial were included. Note that variation from day to day was no greater than within-day variation and was in the range of the coefficient of variation for the whole assay procedure (see text).

was found to have no influence on tissue histamine concentration.

Accuracy of diagnosis of peptic ulcer: Several problems arose in diagnosing peptic ulcer with the degree of accuracy necessary for the trial (Table I), because the findings at endoscopy, radiology and operation did not always agree. In doubtful cases, the endoscopic and radiological examinations were repeated, and the biopsy specimens taken at preoperative endoscopy and at operation were examined histologically. The final decision on the diagnosis was made in difficult cases on the following grounds (Table I): Case 3 had a positive history with typical symptoms and positive endoscopic and radiological findings, but the findings at operation 3 weeks after the diagnostic procedures were unconvincing. Case 4 was thought not to have recurrent ulceration since, except for radiology, all other findings, including clinical questionnaire, were negative. Case 6 had a good history of ulcer and high acid outputs but an ulcer could not be shown convincingly endoscopically, radiologically or at operation. However, his recurrent ulcer was definite enough! In Case 7 neither the ulcer nor the recurrent ulcer could be identified with certainty at operation, but preoperatively the history and high acid outputs were positive and postoperatively high acid outputs, endoscopy, radiology and history were all positive for ulcer, and yet the patient felt in excellent health (Visick grade I). The reoperation was performed 2 weeks after the diagnostic procedures. In Case 12 the operation was performed 3 months after the diagnostic procedures. In all patients in this trial, the indications for surgical treatment were the presence of intractable symptoms of ulcer dyspepsia and the demonstration of an ulcer with a sufficient degree of certainty.

Parietal cell counting: This investigation was described by Martini and Schmidt-Wilcke (1975). In addition to the 4 biopsies in our study, 5 specimens were taken, immediately embedded in fresh rat liver and frozen by liquid nitrogen. From each of the biopsies 5 sections were stained by the succinate dehydrogenase reaction (Pearse, 1968) and the parietal cells were counted in 5 areas by the method of SchmidtWilcke et al. (1974).

Surgical techniques: Selective gastric vagotomy, HeineckeMiculicz pyloroplasty and the resections were performed by techniques described by Seidel et al. (1973b). Posterior gastroenterostomy was carried out at the most dependent part of the stomach near the greater curvature, with a short afferent loop. Statistical methods: Since the gastric mucosal histamine concentrations in duodenal ulcer patients were not normally distributed (Troidl et al., 1976a), the median percentile system was used for parameters of location and variance.
Statistical significance was tested by means of the MannWhitney test and the Wilcoxon test for paired data (Sachs, 1974). For the histamine assay, a quality control was maintained over the whole period of investigation, using control samples prepared in our laboratory. In this way, precision and relative accuracy could be guaranteed for all histamine determinations over a period of at least 18 months (Rohde et al., 1978).

\section{Results}

Part 1

In 5 patients with complete, Hollander-negative vagotomy (Table $I I$ ) the median (first to third quartiles) for gastric histamine concentration was 51.6 (49.7$63.5) \mu \mathrm{g} / \mathrm{g}$. This value was higher by 69 per cent than that of duodenal ulcer patients before or without operation-30.5 (24.0-42.5) $\mu \mathrm{g} / \mathrm{g} ; n=17, P<0.002-$ and higher also than that of control subjects $-42 \cdot 6$ (31.4-49.6) $\mu \mathrm{g} / \mathrm{g} ; n=21, P<0.01$. In 3 patients with recurrent ulcer, however (two of whom had Hollandernegative insulin tests), the mucosal histamine content was as low as that of duodenal ulcer patients without operation (range 32.9-37.0 $\mu \mathrm{g} / \mathrm{g}$ ) (Table $I I$ ).

After various other types of operation for duodenal and gastric ulcer, histamine concentrations in corpus mucosa showed good agreement with these results (Table II). Thus, in 2 duodenal ulcer patients (Cases 13 and 14) who were treated by combined resection and vagotomy, mucosal histamine concentrations of over $50 \mu \mathrm{g} / \mathrm{g}$ were found. Case 13, who had a positive insulin test, had lower histamine values than Case 14, who had a negative insulin test. Thus, it seemed to be the vagotomy and not the resection which was responsible for the increased histamine concentrations in the gastric mucosa of these patients.

Part 2

In all duodenal ulcer patients from part 1 who were treated by selective vagotomy, an increase of gastric mucosal histamine concentration was found 6-11 months after operation (Fig. $1, P<0.01$ by Wilcoxon's test). The median increase was 56 per cent. Again, it was striking that the smallest increase occurred in a patient who had an incomplete vagotomy (Case 15). 


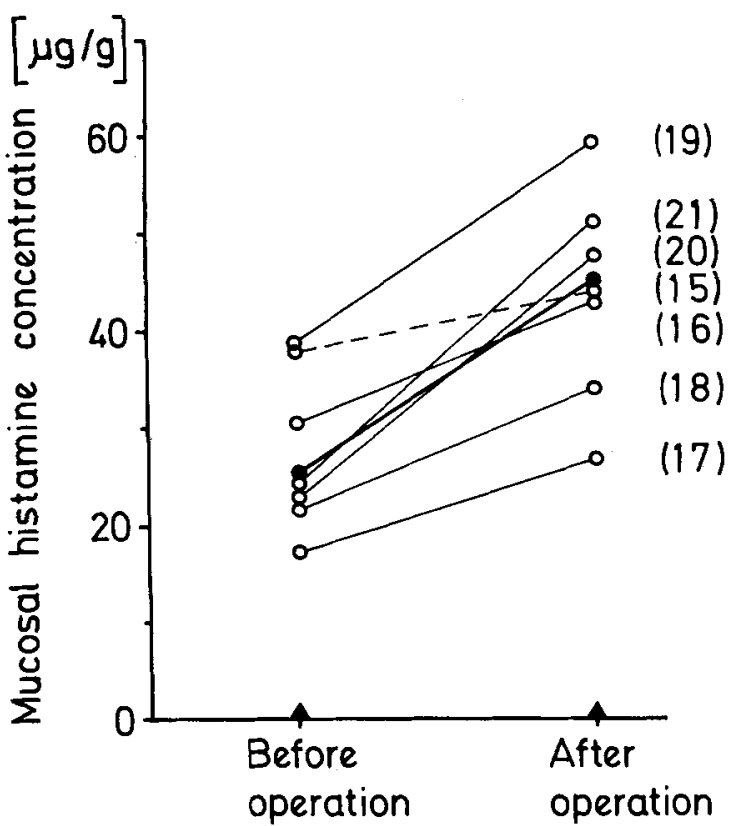

Fig. 1. Histamine concentrations in the corpus mucosa of duodenal ulcer patients before and after selective gastric vagotomy with drainage. Histamine values for each patient represent the arithmetic means of three determinations, as in Table II. In Case 16 the insulin test was omitted because of severe diabetes, but the reduction in PAO was 40 per cent.

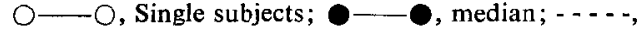
positive Hollander test. Number of patients given in brackets (see Table I).

To test whether the increased mucosal histamine concentration after vagotomy might be due to daily or seasonal influences within this part of the study, mucosal histamine concentration was determined twice within a day (morning and afternoon) and within a time interval of several weeks or months (Table III). The reproducibility of the assessment of histamine concentration was found to be quite satisfactory both within a day and from day to day. Thus, no alteration with time was found which could explain the increase in histamine concentration in corpus mucosa after vagotomy.

Overall clinical assessment and parietal cell counting The overall clinical assessment according to Visick and as modified by Goligher (1975), and the endoscopy, radiology and acid secretion tests in the patients in this study yielded results which were comparable to those reported by several other authors (Troidl et al., 1975b). During the entire period within which this investigation was carried out, no significant change was found in the parietal cell mass of the duodenal ulcer patients after vagotomy.

\section{Discussion}

We found a significant increase in gastric mucosal histamine concentration after vagotomy, which averaged about 50 per cent. Since the methods used were complicated and the observed increases were only in the nanogram range, it must be emphasized that sophisticated techniques were employed to ensure that the results obtained were valid. Thus, for example, the reliability of the histamine assay was confirmed by means of tests of sensitivity, specificity, within-day and day-to-day precision and accuracy using bioassay on guinea-pig ileum as a reference method (Lorenz. et al., 1975; Lorenz et al., 1978; Rohde et al., 1978). Quality control in terms of clinical chemistry was ensured throughout the 18 months of the study, two control samples from a pool prepared in this laboratory being used in each daily series of histamine determinations (Rohde et al., 1978). Six to eleven months were allowed to elapse after the vagotomy operation before its effect was measured, to try to ensure that the results obtained would be representative and valid. Every attempt was made to define as exactly as possible both the precise condition of the subjects who were studied and the conditions of the investigation. Such precision seemed to us to be necessary because of previous conflicting results in studies of mucosal gastrin concentration (Creutzfeldt et al., 1976).

Our findings of lower mucosal histamine concentrations in patients with duodenal ulcer than in 'normal' controls, and of increased mucosal histamine concentrations after vagotomy, suggest that abnormalities of histamine storage might be a feature of duodenal ulcer disease. A similar observation to our findings in patients after vagotomy was made by Lundell et al. (1974), who studied the effect of truncal vagotomy on gastric mucosal histamine in rats. The increase in mucosal histamine concentration which they found in that species might, however, be attributable to an increase in specific endocrine cells (Thunberg, 1967; Håkanson et al., 1967) and not to a change in the mast cells, which have been shown to be the main storage site for histamine in the human stomach (Thunberg, 1967; Håkanson et al., 1969). The results of Lundell et al. (1974) were not in agreement with those of Hutson et al. (1969) and Reichle et al. (1971), who did not find any significant alteration in gastric histamine content after truncal vagotomy in rats. These latter authors, however, had measured not mucosal histamine, but the histamine content of the entire gastric wall. They killed the rats a mere 2 and 3 weeks, respectively, after vagotomy and they tested neither the specificity of their histamine assay nor the completeness of the vagotomies. For these reasons, the results which they obtained have to be interpreted with caution.

There are several possible explanations for the increase in gastric mucosal histamine concentration which we observed after vagotomy in man.

The most likely explanation, in our opinion, is diminished release of histamine from the mucosa after vagotomy, which results in an increased content of stored histamine in the mucosa of the body of the stomach. This hypothesis is supported by previous findings of increased release of histamine from the gastric mucosa of duodinal ulcer patients before operation, resulting in a decreased concentration of histamine in the mucosa (Troidl et al., 1976a). Smith (1959) had previously suggested that incubation with compound 48/80 of gastric tissue obtained from ulcer patients led to more histamine release than simila1 incubation with gastric tissue obtained from patients with gastric carcinoma. In addition, Lundell et al. (1974) found that after truncal vagotomy in rats, newly formed histamine was more slowly mobilized than in control animais under certain conditions. 
A second possibility is increased histamine formation after vagotomy. Indeed, in rats, higher activities of specific histidine decarboxylase were observed after truncal vagotomy than before vagotomy (Håkanson and Liedberg, 1970, 1971; Lundell et al., 1974), but in other species, including man, it seems unlikely that such changes take place (Troidl et al., 1976a).

Decreased inactivation of histamine is a third possibility that is worth considering. In duodenal ulcer patients after vagotomy, however, histamine methyltransferase activity was found to be higher than in control subjects and higher also than in duodenal ulcer patients before operation (Barth et al., 1977). Since this enzyme is, as far as we know, the only significant enzyme responsible for histamine inactivation in human gastric mucosa, this explanation also seems unlikely.

Fourthly, the trophic effects of gastrointestinal hormones, and gastrin in particular, on corpus mucosa after vagotomy might explain the elevated tissue histamine levels. However, throughout the whole period of this study, no increase in parietal cell density was found. We would have expected to find such an increase if significant trophic influences had been at work. Histological examination of biopsy specimens also showed that no significant atrophic gastritis was present in any of the vagotomized patients in this study. (An increased number of mast cells in gastric mucosa has been observed by Siurala and Sundberg (1958) in patients with atrophic gastritis.)

Finally, histamine-forming bacteria (lactobacilli) in the superficial layers of the gastric mucosa could conceivably contribute to the histamine content of the gastric mucosa (Horáková et al., 1971). Bacterial histidine decarboxylase requires an acid medium, however, for optimal activity. This possibility is rendered unlikely by our findings in this study of very low basal acid outputs in patients who nevertheless had high mucosal histamine concentrations, and by our previous findings of normal mucosal histamine concentrations in patients with gastric carcinoma (Troidl et al., 1975a). Furthermore, lactobacilli in particular were found only in rats, sheep and horses, which possess a rumen whose luminal $\mathrm{pH}$ does not regularly fall below 5 (Horáková et al., 1971).

\section{Acknowledgements}

This study was supported by grants from Deutsche Forschungsgemeinschaft (Lo $199 / 7$ and $\mathrm{Ha} \mathrm{461/3).} \mathrm{We} \mathrm{are} \mathrm{very}$ grateful to G. Acker, R. Albrecht, M. Ronzheimer and A. Schmal for their excellent technical assistance. Furthermore, we gratefully thank Professor D. Johnston for his critical comments and for improving the language in this communication.

\section{References}

BARTH H., TROIDL H., LORENZ w. et al. (1977) Histamine and peptic ulcer disease: histamine methyltransferase activity in gastric mucosa of control subjects and duodenal ulcer patients before and after surgical treatment. Agents Actions 6, 75-79.

BJURö T. (1963) Personal communication. Cited according to Dotevall et al. (1963).

BORBOLA J., BIKICH G. and HETENYI G. (1951) Determination of histamine in the gastric juice of man with special respect to duodenal ulcer in the active and inactive stage. Acta Med. Acad. Sci. Hung. 2, 259-268.
BÜCHNER F., SIEBERT P. and MOLLOY P. J. (1928) Über experimentell erzeugte akute peptische Geschwüre des Rattenvormagens. Beitr. Pathol. Anat. Allgem. Pathol. 81, 391425.

BYAR D. P., SIMON R. M., FRIEDEWALD W. T. et al. (1976) Randomized clinical trials. Perspectives on some recent ideas. N. Engl.J. Med. 295, 74-80.

CODE C. F., HURN M. M. and MITCheLl R. G. (1964) Histamine in human disease. Mayo Clin. Proc. 39, 715-737.

CREUTZFELDT W., ARNOLD R., CREUTZFELDT C. et al. (1976) Mucosal gastrin concentration, molecular forms of gastrin, number and ultra-structure of G-cells in patients with duodenal ulcer. Gut 17, 745-754.

DoteVAll G., LINDELl S.-E. and WestLING H. (1963) Histamine studies in a case of Zollinger-Ellison's syndrome. Acta Med. Scand. 174, 325-328.

DOTEVAll G. and WALAN A. (1970) Gastric secretion after stimulation with pentagastrin and histamine. In: CReutzFeld w. (ed.) Origin, Chemistry, Physiology and Pathophysiology of the Gastrointestinal Hormones. Stuttgart, Schattauer, pp. 227-246.

DUNÉR H. and PERNOW B. (1960) Histamine in man under physiological and pathological conditions. Acta Med. Scand. 168, 307-323.

GOLIGHER J. C. (1975) An overall view of the surgical treatment of duodenal ulcer. Adv. Surg. 8, 1-27.

gUgGenheIm M. (1951) Die biogenen Amine und ihre Bedeutung für die Physiologie und Pathologie des pflanzlichen und tierischen Stoffwechsels. Basle, Karger, pp. 458-459.

HAKANSON R. and LIEDBERG G. (1970) The role of endogenous gastrin in the activation of gastric histidine decarboxylase in the rat. Effect of antrectomy and vagal denervation. Eur. J. Pharmacol. 12, 94-103.

HARANSON R. and LIEDBERG G. (1971) Mechanism of activation of rat stomach histidine decarboxylase after vagal denervation. Eur. J. Pharmacol. 16, 78-89.

HÅKANSON R., LILJA B. and owMAN c. (1967) Properties of a new system of amine-storing cells in the gastric mucosa of the rat. Eur. J. Pharmacol. 1, 188-199.

HÅKANSON R., LILJA B. and OWMAN C. (1969) Cellular localization of histamine and monoamines in the gastric mucosa of man. Histochemie 18, 74-86.

HORÁKOVÁ Z., ZIERDT C. H. and BEAVEN M. A. (1971) Identification of Lactobacillus as the source of bacterial histidine decarboxylase in rat stomach. Eur.J. Pharmacol. 16, 66-77.

HUTSON P. G., ZEPPA R. and LEVINE V. (1969) Effect of vagotomy on the content of serotonin and histamine in the gastrointestinal tract. Surg. Forum. 20, 315-317.

INTERNATIONAL MULTICENTRE TRIAL (1975) Treatment of duodenal ulcer by metiamide. Lancet 2, 779-781.

KIRK R. M. (1970) The size of the pyloroduodenal canal: its relation to the cause and treatment of peptic ulcer. Proc. $R$. Soc. Med. 63, 944-946.

LINDELL S. E, and WESTLING H. (1966) Histamine metabolism in man. In: ROCHA E sllva M. (ed.) Histamine and AntiHistaminics. Berlin, Springer-Verlag, pp. 734-788. (Handbook of Experimental Pharmacology, vol. 18, pt 1.)

LIPS A. C. M., VERSCHURE J. C. M. and STRENGERS T. (1947) The histamine level of the blood in patients with gastric or duodenal ulcer before and after treatment with aluminium hydroxyde. Acta Med. Scand. 129, 274-281.

LORENZ W., BENESCH L., BARTH H. et al. (1970) Fluorometric assay of histamine in tissues and body fluids: choice of the purification procedure and identification in the nanogram range. $Z$. Anal. Chem. 252, 94-98.

LORENZ W., DOENICKE A., MEYER R. et al. (1972) An improved method for the determination of histamine re lease in man: its application in studies with propanidid and thiopentone. Eur. J. Pharmacol. 19, 180-190.

LORENZ W. and FEIFEL G. (1970) Neue Gesichtspunkte zur Pathogenese des Stress- und Steroidulkus. Dtsch. Med. Wochenschr. 95, 1848-1850.

LORENZ W., MATEJKA E., SCHMAL A. et al. (1973) A phylogenetic study on the occurrence and distribution of histamine in the gastrointestinal tract and other tissues of man and various animals. Comp. Gen. Pharmacol. 4, 229-250. 
LORENZ W. and PFLEGER K. (1968) Stoffwechsel und physiologische Funktion von Histamin im Magen. Klin. Wochenschr. 46, 57-71.

LORENZ W., SEIDEL W., DOENICKE A. et al. (1974) Elevated plasma histamine concentrations in surgery: causes and clinical significance. Klin. Wochenschr. 52, 419-425.

LORENZ W., TROIDL H., ROHDE H. et al. (1975) Histamine content in human gastric mucosa: reliability of its determination in biopsy specimens. In: Proceedings of the VIth International Congress of Pharmacology, Helsinki. Pharmacological Society of Finland, R 209.

LORENZ W., TROIDL H., ROHDE H. et al. (1978) Histamine and peptic ulcer: a sensitive and specific fluorometric assay for histamine in biopsy specimens of human gastric and duodenal mucosa. Hoppe Seylers Z. Physiol. Chem. (In preparation.)

LUNDELL L., ROSENGREEN E. and SVENSSON S. E. (1974) Alterations in histamine metabolism of rat gastric mucosa following vagotomy. J. Physiol. 242, 209-218.

LYNDON P. J., JOHNSTON D., SMITH R. B. et al. (1973) Further studies on the response to insulin after three types of vagotomy in man. Br. J. Surg. 60, 310.

MARTINI G. A. and SCHMIDT-WILCKE H. A. (1975) Untersuchungen zur Veränderung der Magenschlcimhaut nach Magenoperation unter besonderer Berücksichtigung der Parietalzellzahl. Annual Reports of SFB 122 (Adaptation and Rehabilitation) of DFG, Marburg-Bonn (Bad Godesberg), pp. 248-260.

PARROT J.-L., DEBRAY C. and RICHET C. (1943) Valeur elevée de l'histamine sanguine chez les malades atteints d'ulcère gastroduodenal. Amélioration des signes fonctionnels par un antagoniste de l'histamine. Bull. Mém. Soc. Méd. Hôp. Paris 59, 61-63.

PEARSE A. G. E. (1968) Histochemistry, Theoretical and Applied, 3rd ed. London, Churchill, pp. 475-494.

REICHLE F. A., NEWCOMER D. L., BRINGHAM M. P. et al. (1971) The effect of vagotomy on the histamine content of the gastrointestinal tract. Arch. Surg. 103, 133-139.

RIBOLI R. B. (1940) Istaminoemia e ulcera gastro-duodenale. Arch. Ital. Chir. 59, 485-496.

ROHDE H., LORENZ W., TROIDL H. et al. (1978) Histamine and peptic ulcer: precision and accuracy of the fluorometric histamine assay in biopsy specimens of human gastric mucosa. Clin. Chem. Acta. (In preparation.)

ROHDE H., TROIDL H. and LORENZ w. (1977) Systematic followup: a concept for evaluation of operative results in duodenal ulcer patients. Klin. Wochenschr. 55, 925-932.

SACHS L. (1974) Angewandte Statistik. Planung und Auswertung, Methoden und Modelle, 4th ed. Berlin, Springer-Verlag, p. 230.

SCHMIDT-WILCKE H. A., HAAKE U. and RIECKEN E. O. (1974) Investigations on the relationship between maximal acid output and parietal cells in gastric mucosa biopsies with special reference to duodenal ulcer. Acta Hepat. Gastroentol. 21, 297-302.
SEIDEL W., LORENZ W., DOENICKE A. et al. (1973a) Histaminfreisetzung beim Menschen und Stressulkuspathogenese. $Z$. Gastroenterol. 11, 297-300.

SEIDEL W., TROIDL H., LORENZ w, et al. (1973b) Eine prospektive, kontrollierte Studie zur selektiven Vagotomie beim chronischen Duodenalulkus: Frühergebnisse mit einer standardisierten Operationsauswahl und Operationstechnik. Klin. Wochenschr. 51, 477-486.

SHEINER H. J., DUTHIE H. L., BARBER D. C. et al. (1975) The effect of highly selective vagotomy and truncal vagotomy with pyloroplasty on gastric emptying of solid food in man. $B r$.J. Surg. 62, 163-164.

SHIMKIN M. B., ZON L. and CRIGLER C. W. (1943) Blood histamine in gastric cancer and peptic ulcer. Proc. Soc. Exp. Biol. Med. 52, 335-338.

SIURALA M. and SUNDBERG M. (1958) Occurrence of mast cells in the gastric mucosa under normal and pathological conditions. Ann. Med. Exp. Biol. Fenn. 36, 270-284.

SMIтH A. N. (1959) The distribution and release of histamine in human gastric tissues. Clin. Sci. 18, 533-541.

SURKES A. W. (1948) Der Histamingehalt im Blut von Ulkuskranken. Praxis 37, 264-266.

THUNBERG R. (1967) Localization of cells containing and forming histamine in the gastric mucosa of the rat. Exp. Cell. Res. 46, 108-115.

TROIDL H., LORENZ W., ROHDE H. et al. (1975a) Histamine content in human gastric mucosa: its relation to the pentagastrin-stimulated acid secretion and to selectivegastric vagotomy with drainage. Agents Actions 5, 427428.

TROIDL H., LORENZ W., ROHDE H. et al. (1975b) Was ist gesichert in der Behandlung der Ulkuskrankheit durch Vagotomie? Internist 16, 575-582.

TROIDL H., LORENZ W., ROHDE H. et al. (1976a) Histamine and peptic ulcer: a prospective study of mucosal histamine concentration in duodenal ulcer patients and in control subjects suffering from various gastrointestinal diseases. Klin. Wochenschr. 54, 947-956.

TROIDL H., ROHDE H. and LORENZ w. (1976b) Histamine concentrations in gastric mucosa of duodenal ulcer patients before and 1 year after selective gastric vagotomy. $\mathrm{Br} . J$. Surg. 63, 155.

VARCO R, L., CODE C. F., WALPOLE S. H. et al. (1941) Duodenal ulcer formation in the dog by intramuscular injection of a histamine-beeswax mixture. Am. J. Physiol. 133, 475-481.

WEINBERG J.A. (1964) Pyloroplasty and vagotomy for duodenal ulcer. Curr. Probl. Surg. April.

Paper accepted 8.8.1977 